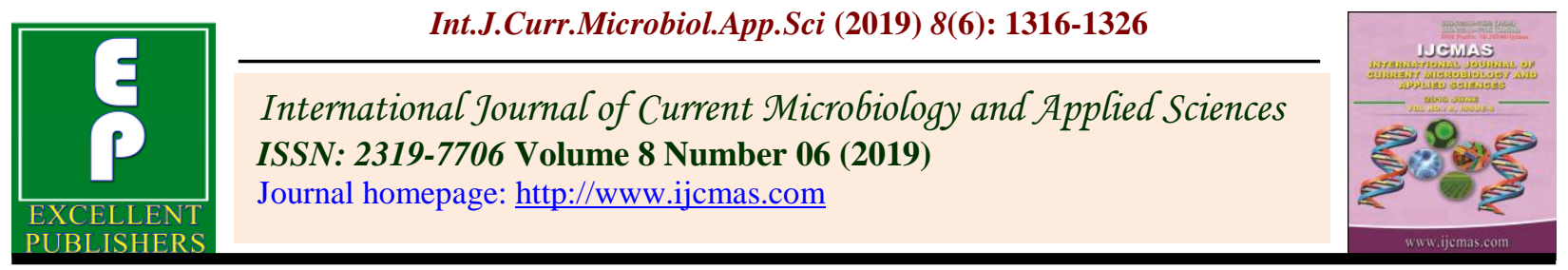

Original Research Article

https://doi.org/10.20546/ijcmas.2019.806.159

\title{
Effect of Biofertilizers and Vesicular Arbuscular Mycorrhizae on Holy Basil (Ocimum sanctum)
}

\author{
J.M. Harishkumar, C. Karishmaa, N. Meenaloshini, K. Nagavalli, P. Pavithra, \\ A. Sowbejan, S.J. Aruna* and M. Theradimani \\ Department of Plant Physiology and Microbiology, College of Agricultural Technology, \\ Theni, India \\ *Corresponding author
}

\begin{abstract}
A B S T R A C T
Keywords

Azospirillum,

Azotobacter,

Phosphate

solublizing bacteria,

Holy basil,

Vesicular

Arbuscular

Mycorrhizae

Article Info

Accepted:

12 May 2019

Available Online:

10 June 2019

Ocimum sanctum is an important medicinal and aromatic plant widely grown tropical and subtropical climate in India. The present investigation was conducted to study the effect of biofertilizers and Vesicular Arbuscular Mycorrhizae (VAM) on Basil (Ocimum sanctum). In this biofertilizers viz., Azospirillum, Azotobacter, Phosphate solublizing bacteria (PSB), VAM and in various combinations were applied and observed the plant height, girth of plant, number of branches, number of leaves per plant, leaf area index, nitrogen and phosphorous content. Results revealed that the combined soil application of Azotobacter (25\%), Azospirillum (25\%), PSB (25\%) and VAM $(25 \%)$ showed better results than the individual applications. The combined effect of biofertilizers and VAM improves the plant growth and productivity.
\end{abstract}

\section{Introduction}

The herb, Holy basil (Ocimum sanctum L.) has been known for its curative properties and has been utilized as antimycotoxic, analgestic, antibacterial, antihaemorrhagic, antioxidant properties and it is considered as a good rejuvenator (Ghosh, 1995). A wide range of chemical compounds including coumestans, triterpenes and their glycosides have been known to possess the medicinial uses composition and the pharmacological profile as a medicinal plant. It bear major essential oils like camphor, citral, linalool, eugenol, thymol, geraniol and other constituents are known to use in perfumery and cosmetic industries (Gupta et al., 2000). Biofertilizers are organic products containing specific beneficial microorganisms in concentrated forms derived from the rhizosphere (Mishra and Dadhich, 2010).

In recent years biofertilizers have emerged as promising component of integrating nutrient supply system in sustainable agriculture. Biofertilizers provide plant with their nutritional requirements without undesirable impact on the environment. Biofertilizers are organic products containing specific microorganisms in concentrated forms 
derived from the soil root zone (Mishra and Dadhich, 2010). In recent years biofertilizers have emerged as promising component of integrating nutrient supply system in agriculture. Microbial fertilizers are considered as an important part of environment friendly sustainable agricultural practices with low cost inputs mainly including nitrogen fixing, phosphate solubilizing and plant promoting microorganisms. Biofertilizers are important for medicinal and aromatic plants to produce the best product in both quantity and quality and it is also safe for human, animal and the environment.

The VAM fungi and soil microorganisms develop special characteristic structures called as arbuscles and vesicles. The arbuscules help in the transfer of nutrients from the soil into the root system (Divya, 2015). In view of this effect of VAM and soil microorganisms is important thrust area in plant growth and development especially in medicinal plants. Vesicular Arbuscular Mycorrhizal fungi improve plant growth through phosphorous nutrition. In addition to phosphorous they also help in the uptake of other nutrient element. Nutrient absorption by fungal symbionts is due to external hyphae of the fungus proliferating beyond the nutrient depletion zone and reaching the source of nutrient. The improved plant growth promoting substances, tolerance to drought, salinity and transplantation shock, resistance to soil-borne pathogen and synergetic interaction with other beneficial microorganism (Sandhya et al., 1989).

VAM fungi inoculation is one of the promising tools for the conservation and sustainable maintenance of medicinal herbs. The objective of this work was to study the effect of the application of VAM fungi and biofertilizers on the vegetative growth and chemical composition of basil.

\section{Materials and Methods}

The investigation on effect of biofertilizers and VAM on Basil was carried out in the Department of Plant Physiology and Microbiology, College of Agricultural Technology, Theni during the year 20182019. The pot culture experiment was conducted in the nursery located at the College of Agricultural Technology, Kullapuram, Theni.

The experimental site is situated in the Southern Agro climatic zone of Tamil Nadu at $10^{\circ} 5^{\prime}$ North latitude and $77^{\circ} 5^{\prime}$ East longitude. The bio-inoculants Azospirillum and Azotobacter were collected from Biofertilizer production unit, Karukodai, Uthamapalayam, Theni district, Tamil Nadu. PSB and VAM were collected from ADA Office, Andipatti, Theni district, Tamil Nadu.

\section{Pot culture experiment}

The experiment was laid out in completely randomized design with 11 treatments and 3 replications. The experimental set up was homogenous, which was carried out in pots. The nutrient status of the experimental set up was unique.

So we select the Completely Randomized Block Design (CRD) as the experimental design. After seedlings of Ocimum sanctum were transplanted in each pots. The pots were provided with water facilities. There were 11 treatments resulting from Biofertilizers like Azospirillum, Azotobacter, Phosphobacteria, VAM and control. The pots were maintained in the open shade at the temperature of $27^{\circ} \mathrm{C}$ - $30^{\circ}$ C. After $15^{\text {th }}, 30^{\text {th }}$ and $45^{\text {th }}$ days of growth we observed Plant Height, Number of Leaves, Number of Branches, Girth of the plant and Leaf Area Index. The biofertilizers dose were calculated as per the recommendations per ha. 


\section{Assessing the plant growth parameters}

\section{Plant height}

Plant height $(\mathrm{cm})$ was measured by following the procedure of Lindarman (1983), the plant height of all the plants and their mean height was calculated.

\section{Number of branches per plant}

According to Bolan (1991), the total number branches per plant was recorded at $30^{\text {th }}, 45^{\text {th }}$ days and expressed in numbers.

\section{Number of leaves}

(Indicates a plant's physiological age): the number of leaves per plant was recorded at $15^{\text {th }}, 30^{\text {th }}, 45^{\text {th }}$ days and expressed in numbers.

\section{Leaf area index}

Leaf area index is calculated by dividing the leaf area per plant to the ground area.

$$
\text { LAI }=\frac{\text { Leaf area per plant }}{\text { Ground area occupied }}
$$

Leaf Area $=$ LBK $\times$ Number of leaves per plant

\section{Girth of the plant}

The value is estimated by surrounding the thread around the girth and the thread length is measured using scale.

\section{Assessment of VAM fungal association in roots}

The VAM associations with the inoculated roots of the individual plants were assessed. In this method, roots infected with VAM biofertilizers were collected. They are chopped into pieces and they were bleached with $\mathrm{H}_{2} \mathrm{O}_{2}$ solution. Then staining was performed with Typhan Blue solution. Following this, destaining was performed and we kept it for overnight. We observed VAM infection under microscope.

\section{Nitrogen and Phosphorus estimation}

Nitrogen and Phosphorus content in the leaves was estimated by the Macrokjeldhal and Colorimetric method.

\section{Statistical analysis}

Data were subjected to analysis of variance (Gomez and Gomez, 1984). Duncan's Multiple Range Tests was used to separate means. Percent values were transformed by arcsine or square root.

\section{Results and Discussion}

In the present study the maximum girth (1.8 $\mathrm{cm})$ was observed in the treatment which involve integrated application of biofertilizers (Azotobacter 25\% + PSB 25\% + VAM 50\%) T8 on par with (Azotobacter 100\%) T2 followed by (VAM 100\%) T3 followed by (Azotobacter 50\% + VAM 50\% T5). The minimum girth $(1.6 \mathrm{~cm})$ was observed in control (T11) (Table 1).

The seedling rootstocks with VAM fungi shows increased stem diameter (Ikram et al., 1992). The maximum leaf area index was observed in the treatment T6 which involves the application of Azospirillum 50\% + VAM $50 \%$ on par with T7 (PSB 50\% + VAM 50\%) records LAI-1.2 in plants. The minimum LAI was observed in T11 - control which gives LAI - 0.7 (Table 2).

The combined application of VAM and Azotobacter increases leaf area per plant (Mahantesh Sajan, 2002). The treatment T10 
recorded more number (17) of branches which involves the integrated application of biofertilizers (T10 - Azospirillum 25\% + Azotobacter 25\% + PSB 25\% + VAM 25\%) followed by (T7- PSB 50\% + VAM 50\%) which gives 16 number of branches.

The less number of branches (5) was observed in treatment (T5 - Azotobacter 25\% + VAM 25\%) (Table 3).

The treatment $\mathrm{T} 8$ recorded more number of leaves (95) which involves application of biofertilizers (T8 - Azotobacter 25\% + PSB $25 \%+$ VAM $50 \%$ ). The less number of leaves (66) was observed in control (T11) (Table 4).

In earlier results of several field experiments indicated that crops inoculated with Azotobacter shows increase in yield from 7 to $12 \%$ over the uninoculated crops (Mishustin and Shilnikova, 1968).

Azotobacter pose ability to produce vitamins and growth substances which enhances the seed germination (Shende et al., 1977).

The free living, gram negative, motile and mesophilic Azotobacter spp are capable of fixing an average of $20 \mathrm{~kg}$ of N/ha for a year (Rawia et al., 2009).

Yield increased ranges from 2 to 45 per cent in vegetables, 9 to 24 per cent in sugarcane, 0 to 31 per cent in maize, sorghum, mustard etc., on Azotobacter inoculation (Pandey and Kumar, 1989). Besides $\mathrm{N}_{2}$ fixation, Azotobacter synthesizes and secretes considerable amounts of biologically active substances like B vitamins, nicotinic acid, pantothenic acid, biotin, heteroxins, gibberellins etc. which enhance root growth of plants (Rao, 1986). VAM may be an alternative to rising agricultural energy and to increase crop yield and fertilizer cost. Mycorrhizal interactions in sustainable agriculture (Paul Schiener and Bethlenfalvay, 1995) and he explained about the enhancement of soil structure by applying VAM to sustainable farming. Possible role of soil microorganisms in aggregation in soils (Tisdall, 1994) and here the stabilization of soil fertility by some soil microbes like VAM is explained. Growth of VAM mycelium through bulk soil (Caml et al., 1991) Soil mycelia of VAM fungi not only extended the range of plant roots for nutrient uptake but also may connect roots, allowing the transfer of small amounts of nutrients between plants.

The role of the external mycelial network of VAM fungi, a study of $\mathrm{C}$ transfer between plants interconnected by common mycelium. i.e., the transfer of $\mathrm{C}_{14}$ from Lolium perenne donor to Plantago lanceolata receiver mediated by VAM when the sp grown together or separately nutrient transfer between the root zones of soybean and maize plants connected by a common mycorrhizal mycelium (Bethlenfalvay et al., 1991), VAM as a symbiotic fungus root association can greatly increase the utilization of nutrients. VAM affect lowland tropical rain forest plant growth.

Dual symbiosis between VAM and Azotobacter enhances the leaf yield and also the biomasses and nutrient uptake (Arora et al., 2016).

In the present study, the treatment T10 gives maximum plant height $(46 \mathrm{~cm})$ which involves the integrated application of biofertilizers (T10-Azospirillum 25\%+ Azotobacter 25\% + PSB 25\% + VAM 25\%).

The minimum plant height $(30.8 \mathrm{~cm})$ was observed in control (T11) (Table 5). The growth of plants could be enhanced effectively by the combined inoculation of VAM and Azospirillum (Pacovsky, 1988 and Subba Rao et al., 2001). 
Table.1 Effect of biofertilizers on Stem girth $(\mathrm{cm})$

\begin{tabular}{|c|c|c|c|}
\hline Treatment & $15^{\text {th }}$ day & $30^{\text {th }}$ day & $45^{\text {th }}$ day \\
\hline T1 - Azospirillum (100\%) & 0.7 & 1.3 & 1.7 \\
\hline T2 - Azotobacter (100\%) & 0.8 & 1.2 & 1.8 \\
\hline T3 - VAM (100\%) & 0.8 & 1.4 & 1.8 \\
\hline T4 - PSB (100\%) & 0.7 & 1.1 & 1.7 \\
\hline T5 - Azotobacter (50\%) + VAM (50\%) & 0.8 & 1.4 & 1.8 \\
\hline $\begin{array}{l}\text { T6 - Azospirillum (50\%) + VAM } \\
(50 \%)\end{array}$ & 0.8 & 1.3 & 1.6 \\
\hline T7- PSB $(50 \%)+$ VAM (50\%) & 0.7 & 1.3 & 1.7 \\
\hline $\begin{array}{l}\text { T8 - Azotobacter (25\%) + PSB (25\%) } \\
+ \text { VAM }(25 \%)\end{array}$ & 0.9 & 1.5 & 1.8 \\
\hline $\begin{array}{l}\text { T9 - Azospirillum (25\%) + PSB (25\%) } \\
+ \text { VAM (50\%) }\end{array}$ & 0.8 & 1.4 & 1.7 \\
\hline $\begin{array}{l}\text { T10 - Azotobacter }(25 \%)+ \\
\text { Azospirillum }(25 \%)+\text { PSB }(25 \%)+ \\
\text { VAM }(25 \%)\end{array}$ & 0.7 & 1.3 & 1.7 \\
\hline \multirow[t]{2}{*}{ T11 - Control } & 0.8 & 1.2 & 1.6 \\
\hline & $\begin{array}{l}\text { SEd }=0.016 \\
\operatorname{CD}(0.01)=0.04 \\
\operatorname{CD}(0.05)=0.03\end{array}$ & $\begin{array}{l}\text { SEd }=0.027 \\
\text { CD }(0.01)=0.07 \\
\text { CD }(0.05)=0.05\end{array}$ & $\begin{array}{l}\text { SEd }=0.035 \\
\operatorname{CD}(0.01)=0.09 \\
\operatorname{CD}(0.05)=0.07\end{array}$ \\
\hline
\end{tabular}

Table.2 Effect of biofertilizers on Leaf Area Index

\begin{tabular}{|c|c|c|c|}
\hline Treatment & $15^{\text {th }}$ day & $30^{\text {th }}$ day & $45^{\text {th }}$ day \\
\hline T1 - Azospirillum (100\%) & 0.16 & 0.6 & 1.1 \\
\hline T2 - Azotobacter (100\%) & 0.11 & 0.3 & 1.0 \\
\hline T3 - VAM (100\%) & 0.15 & 0.4 & 0.9 \\
\hline T4 - PSB (100\%) & 0.09 & 0.1 & 0.8 \\
\hline T5 - Azotobacter $(50 \%)+$ VAM $(50 \%)$ & 0.1 & 0.2 & 1.0 \\
\hline T6 - Azospirillum (50\%) + VAM (50\%) & 0.13 & 0.5 & 1.2 \\
\hline T7- PSB (50\%) + VAM (50\%) & 0.11 & 0.5 & 1.2 \\
\hline $\begin{array}{l}\text { T8 - Azotobacter }(25 \%)+\text { PSB }(25 \%)+ \\
\text { VAM (25\%) }\end{array}$ & 0.17 & 0.3 & 0.9 \\
\hline $\begin{array}{l}\text { T9 - Azospirillum (25\%) + PSB (25\%) } \\
+ \text { VAM (50\%) }\end{array}$ & 0.16 & 0.6 & 0.8 \\
\hline $\begin{array}{l}\text { T10 - Azotobacter }(25 \%)+\text { Azospirillum } \\
(25 \%)+\text { PSB }(25 \%)+\text { VAM }(25 \%)\end{array}$ & 0.18 & 0.6 & 0.9 \\
\hline T11 - Control & 0.14 & 0.2 & 0.7 \\
\hline & $\begin{array}{c}\text { SEd }=0.003 \\
\mathrm{CD}(0.01)=0.008 \\
\mathrm{CD}(0.05)=0.006\end{array}$ & $\begin{array}{c}\text { SEd }=0.08 \\
\text { CD }(0.01)=0.17 \\
\text { CD }(0.05)=0.23\end{array}$ & $\begin{aligned} \text { SEd } & =0.017 \\
\mathrm{CD}(0.01) & =0.05 \\
\mathrm{CD}(0.05) & =0.03\end{aligned}$ \\
\hline
\end{tabular}


Table.3 Effect of biofertilizers on number of branches

\begin{tabular}{|c|c|c|c|}
\hline Treatment & $15^{\text {th }}$ day & $30^{\text {th }}$ day & $45^{\text {th }}$ day \\
\hline T1 - Azospirillum (100\%) & - & 8 & 16 \\
\hline T2 - Azotobacter (100\%) & - & 6 & 12 \\
\hline T3 - VAM (100\%) & - & 7 & 10 \\
\hline T4 - PSB (100\%) & - & 4 & 5 \\
\hline T5 - Azotobacter (50\%) + VAM (50\%) & - & 7 & 9 \\
\hline T6 - Azospirillum (50\%) + VAM (50\%) & - & 10 & 12 \\
\hline T7- PSB (50\%) + VAM (50\%) & - & 13 & 16 \\
\hline $\begin{array}{l}\text { T8 - Azotobacter }(25 \%)+\text { PSB }(25 \%)+ \\
\text { VAM }(25 \%)\end{array}$ & - & 12 & 16 \\
\hline $\begin{array}{l}\text { T9 - Azospirillum (25\%) + PSB (25\%) } \\
+ \text { VAM (50\%) }\end{array}$ & - & 7 & 12 \\
\hline $\begin{array}{l}\text { T10 - Azotobacter (25\%) + Azospirillum } \\
(25 \%)+\text { PSB }(25 \%)+\text { VAM }(25 \%)\end{array}$ & - & 12 & 17 \\
\hline T11 -Control & - & 8 & 11 \\
\hline & - & $\begin{array}{l}\text { SEd }=0.47 \\
\operatorname{CD}(0.01)=1.32 \\
\operatorname{CD}(0.05)=0.97\end{array}$ & $\begin{array}{c}\text { SEd }=0.22 \\
\operatorname{CD}(0.01)=2.32 \\
\operatorname{CD}(0.05)=0.62\end{array}$ \\
\hline
\end{tabular}

Table.4 Effect of biofertilizers on number of leaves

\begin{tabular}{|c|c|c|c|}
\hline Treatment & $15^{\text {th }}$ day & $30^{\text {th }}$ day & $45^{\text {th }}$ day \\
\hline T1 - Azospirillum (100\%) & 13 & 40 & 92 \\
\hline T2 - Azotobacter (100\%) & 11 & 24 & 79 \\
\hline T3 - VAM (100\%) & 15 & 38 & 82 \\
\hline T4 - PSB (100\%) & 12 & 22 & 68 \\
\hline T5 - Azotobacter (50\%) + VAM (50\%) & 13 & 24 & 72 \\
\hline T6 - Azospirillum (50\%) + VAM (50\%) & 15 & 43 & 90 \\
\hline T7- PSB (50\%) + VAM (50\%) & 13 & 47 & 87 \\
\hline $\begin{array}{l}\text { T8 - Azotobacter }(25 \%)+\text { PSB }(25 \%)+ \\
\text { VAM }(25 \%)\end{array}$ & 17 & 52 & 95 \\
\hline $\begin{array}{l}\text { T9 - Azospirillum (25\%) + PSB (25\%) } \\
+ \text { VAM (50\%) }\end{array}$ & 14 & 40 & 73 \\
\hline $\begin{array}{l}\text { T10 - Azotobacter }(25 \%)+\text { Azospirillum } \\
(25 \%)+\text { PSB }(25 \%)+\text { VAM }(25 \%)\end{array}$ & 17 & 47 & 92 \\
\hline \multirow[t]{2}{*}{ T11-Control } & 14 & 28 & 66 \\
\hline & $\begin{array}{c}\text { SEd }=0.29 \\
\operatorname{CD}(0.01)=0.84 \\
\operatorname{CD}(0.05)=0.62\end{array}$ & $\begin{array}{c}\text { SEd }=0.47 \\
\operatorname{CD}(0.01)=1.34 \\
\operatorname{CD}(0.05)=0.98\end{array}$ & $\begin{array}{c}\mathrm{SEd}=1.41 \\
\mathrm{CD}(0.01)=3.98 \\
\mathrm{CD}(0.05)=2.93\end{array}$ \\
\hline
\end{tabular}


Table.5 Effect of biofertilizers on plant height $(\mathrm{cm})$

\begin{tabular}{|c|c|c|c|}
\hline Treatment & $15^{\text {th }}$ day & $30^{\text {th }}$ day & $45^{\text {th }}$ day \\
\hline T1 - Azospirillum (100\%) & 15.5 & 35.5 & 42 \\
\hline T2 - Azotobacter (100\%) & 14.1 & 18.1 & 32 \\
\hline T3 - VAM (100\%) & 16.4 & 29.5 & 44.5 \\
\hline T4 - PSB (100\%) & 12.9 & 19.8 & 35 \\
\hline $\begin{array}{l}\text { T5 - Azotobacter }(50 \%)+\text { VAM } \\
(50 \%)\end{array}$ & 14.7 & 19.7 & 36.5 \\
\hline $\begin{array}{l}\text { T6 - Azospirillum (50\%) + VAM } \\
(50 \%)\end{array}$ & 17.4 & 33.8 & 43.5 \\
\hline T7- PSB $(50 \%)+$ VAM (50\%) & 12.9 & 27 & 43 \\
\hline $\begin{array}{l}\text { T8 - Azotobacter (25\%) + PSB } \\
(25 \%)+\text { VAM }(25 \%)\end{array}$ & 15.8 & 32.1 & 43.5 \\
\hline $\begin{array}{l}\text { T9 - Azospirillum (25\%) + } \\
\text { PSB }(25 \%)+\text { VAM }(50 \%)\end{array}$ & 14 & 34 & 39 \\
\hline $\begin{array}{l}\text { T10 - Azotobacter }(25 \%)+ \\
\text { Azospirillum }(25 \%)+\text { PSB }(25 \%) \\
+ \text { VAM }(25 \%)\end{array}$ & 19.1 & 39 & 46 \\
\hline T11 - Control & 8.9 & 16.6 & 30.8 \\
\hline & $\begin{array}{c}\text { SEd }=0.35 \\
\operatorname{CD}(0.01)=1.01 \\
\operatorname{CD}(0.05)=0.74\end{array}$ & $\begin{array}{c}\text { SEd }=0.61 \\
\operatorname{CD}(0.01)=1.74 \\
\operatorname{CD}(0.05)=1.28\end{array}$ & $\begin{array}{c}\text { SEd }=0.68 \\
\operatorname{CD}(0.01)=1.92 \\
\operatorname{CD}(0.05)=1.41\end{array}$ \\
\hline
\end{tabular}

Table.6 Effect of biofertilizers on phosphorus content

\begin{tabular}{|c|c|}
\hline Treatment & $P$ content $(\%)$ \\
\hline T1 - Azospirillum (100\%) & 0.002 \\
\hline T2 - Azotobacter (100\%) & 0.003 \\
\hline T3 - VAM (100\%) & 0.002 \\
\hline T4 - PSB (100\%) & 0.002 \\
\hline T5 - Azotobacter $(50 \%)+$ VAM (50\%) & 0.002 \\
\hline T6 - Azospirillum (50\%) + VAM (50\%) & 0.004 \\
\hline T7- PSB (50\%) + VAM (50\%) & 0.003 \\
\hline $\begin{array}{l}\text { T8 - Azotobacter (25\%) + PSB (25\%) + } \\
\text { VAM }(25 \%)\end{array}$ & 0.003 \\
\hline $\begin{array}{l}\text { T9 - Azospirillum }(25 \%)+\operatorname{PSB}(25 \%) \\
+\operatorname{VAM}(50 \%)\end{array}$ & 0.003 \\
\hline $\begin{array}{l}\text { T10 - Azotobacter (25\%) + Azospirillum (25\%) + PSB (25\%) + VAM } \\
(25 \%)\end{array}$ & 0.003 \\
\hline T11-Control & 0.001 \\
\hline $\begin{array}{c}\text { SEd } \\
\text { CD }(0.01) \\
\text { CD }(0.05)\end{array}$ & $\begin{array}{c}0.0014 \\
0.002 \\
0.004\end{array}$ \\
\hline
\end{tabular}


Table.7 Effect of biofertilizers on nitrogen content

\begin{tabular}{|c|c|}
\hline Treatment & $\mathrm{N}$ content (\%) \\
\hline T1 - Azospirillum (100\%) & 0.952 \\
\hline T2 - Azotobacter (100\%) & 1.148 \\
\hline T3 - VAM (100\%) & 1.036 \\
\hline T4 - PSB (100\%) & 1.232 \\
\hline T5 - Azotobacter (50\%) + VAM (50\%) & 1.568 \\
\hline T6 - Azospirillum (50\%) + VAM (50\%) & 0.896 \\
\hline T7- PSB (50\%) + VAM (50\%) & 0.868 \\
\hline T8 - Azotobacter (25\%) + PSB (25\%) + VAM (25\%) & 1.008 \\
\hline T9 - Azospirillum (25\%) + PSB (25\%) + VAM (50\%) & 1.652 \\
\hline $\begin{array}{l}\text { T10 - Azotobacter (25\%) + Azospirillum (25\%) + PSB (25\%) + VAM } \\
(25 \%)\end{array}$ & 0.952 \\
\hline T11 -Control & 0.644 \\
\hline $\begin{array}{c}\text { SEd } \\
\text { CD }(\mathbf{0 . 0 1}) \\
\text { CD }(0.05)\end{array}$ & $\begin{array}{c}0.05 \\
0.03 \\
0.018\end{array}$ \\
\hline
\end{tabular}

Treatments

\begin{tabular}{|l|l|}
\hline T1 & Azospirillum $(\mathbf{1 0 0} \%)$ \\
\hline T2 & Azotobacter $(100 \%)$ \\
\hline T3 & VAM (100\%) \\
\hline T4 & PSB (100\%) \\
\hline T5 & Azotobacter $(50 \%)+$ VAM (50\%) \\
\hline T6 & Azospirillum $(50 \%)+$ VAM (50\%) \\
\hline T7 & PSB (50\%) + VAM (50\%) \\
\hline T8 & Azotobacter (25\%) + PSB (25\%) + VAM (50\%) \\
\hline T9 & Azospirillum $(25 \%)+$ PSB (25\%) + VAM (50\%) \\
\hline T10 & Azotobacter $(25 \%)+$ Azospirillum $(25 \%)+$ PSB $(25 \%)+$ VAM $(25 \%)$ \\
\hline T11 & Control \\
\hline
\end{tabular}

Interaction between VAM and Azotobacter and their effects on rhizosphere microflora and plant growth (Bagyaraj, 1978) and he concluded that the association of VAM and Azotobacter gives more number of bacteria and actinomycetes population than inoculated with alone. The interactions of Azotobacter chrococcum and Piriformospora indica give beneficial effects on shoot length, Root length, Fresh root and shoot weight and panicle number (Kamil prajapati, 2008).
Combined effects of Piriformospora indica and Azotobacter chrococcum enhance plant growth, antioxidant potential and steriol glycoside content in Steria rebaudiana. It enhances the plant growth parameters like plant height, Total dry weight, leaf yield and also the biomass was associated with chlorophyll content and nutrient uptake. The treatment T10 recorded more phosphorus percent which involves the application of (T10 - Azospirillum 25\% + Azotobacter 25\% 
+ PSB $25 \%+$ VAM $25 \%(0.003 \%)$ followed by (T8 - Azotobacter 25\% + PSB 25\% + VAM $50 \%-0.003 \%$ ) it on par with (T9 Azospirillum 25\% + PSB 25\% + VAM 50\% $0.003 \%$ ) and the minimum percent in T11 control $(0.001 \%)$ (Table 6).

Effect of dual inoculation of Azotobacter and Mycorrhiza with $\mathrm{N}$ and $\mathrm{P}$ fertilizer rates on grain yield and some characteristics of spring sunflower (Mirzakhani et al., 2009) These interactions gives increased grain yield, harvest index, hectolite weight, root dry weight, seed yield, mycorrhizal colonization on root in peach. VAM and Azospirillum greatly enhance the mobilization of $\mathrm{P}$ and $\mathrm{N}$ in the crop plants (Baldani et al., 1983; Harley, 1989). The treatment T10 recorded more phosphorus percent which involves the application of T9 - Azospirillum (25\%) + PSB $(25 \%)+$ VAM $(50 \%)(1.652 \%)$ followed by (T5 - Azotobacter (50\%) + VAM (50\%) 1.568 and the minimum percent in T11 control (0.644\%) (Table 7).

Early reports on growth and yield of crop plants could be enhanced effectively by increasing the uptake of $\mathrm{P}$ and $\mathrm{N}$ from soil by combined inoculation of VAM and Azospirillum (Pacovsky, 1988). VAM and Azospirillum sp. together provide a means by which cereal plants lacking symbiotic $\mathrm{N}$ fixers (Rhizobium) could compensate the $\mathrm{N}$ deficiency and he also suggested that combined inoculation of Azospirillum and VAM increase the uptake of $\mathrm{N}$ greater than the estimated needs (Barea et al., 1983). Increase in plant dry weight, shoot to root ratios and the $\mathrm{N}$ content of dually infected plants could be accounted for by summing VAM and Azospirillum (Pacovsky et al., 1985). The use of phosphate solubilizing bacteria as inoculants simultaneously increases Phosphorous uptake by the plant and crop yield. PSB not only increased P availability in the soil but also performed as plant growth promoting bacteria. PSB improve $\mathrm{N}, \mathrm{P}$ and $\mathrm{K}$ nutrition and may function as biocontrol agents of photopathogenic fungi, synthesizing phytohormones in the rhizophere, and as a result may promote plant growth and development. PSB play a vital role in $\mathrm{P}$ availability from both organic and mineral sources (Iyer and Rajkumar, 2017). This role in attributed to the ability of PSB to produce low molecular weight acids (Al-Enazy et al., 2017) such as formic, acetic, propionic, lactic, glycoliuc, fumaric and succinic acid (Rashid et al., 2004) which use their carboxyl and hydroxyl groups to chelate cation such as $\mathrm{Ca}^{+2}$ and $\mathrm{Mg}^{+2}$. This chelation solubilizes insoluble soil phosphorous (Sharma et al., 2013).

In conclusion, the chemical fertilizers possess threat to the environment so the use of biofertilizers is both economic and environmental friendly. In this study we highlighted use of VAM and $\mathrm{N}$ and $\mathrm{P}$ biofertilizers for the development of growth parameters on Basil. Treatment of biofertilizers in combination with Azospirillum, Azotobacter, PSB and VAM has significantly enhanced the growth parameters which include plant height, girth of the plant, number of leaves per plant, number of branches per plant, leaf area index and $\mathrm{N}$ and $\mathrm{P}$ content. This study has revealed that there is a huge potential for the use of biofertilizer and VAM in holy basil.

\section{References}

Al Enazy A.A.R., S.S. Al Oud, F.N. Al Barakah and A.R. Usman, 2017. Role of microbial inoculation and industrial by product phosphogypsum in growth and nutrient uptake of maize (Zea mays L.) grown in calcareous soil. J. Sci. Food. Agri., 97(11): 252- 264. 
Baldani, V.L., J.I. Baldani and J. Dobereiner, 1983. Effects of Azospirillum inoculation on root infection and nitrogen incorporation in wheat. Can. J. Mirobiol., 29: 924-929.

Barea, J.M., A.F. Bonis and J. Olivares, 1983. Interactions between Azospirillum and VA mycorrhiza and their effects on growth and nutrition of maize and ryegrass. Soil Biol. Biochem., 15: 705709.

Bolan, 1991. Quality enhancement studies of growth and nutrient content in Phaseolus aureus, biofertilizers. J. Nat. Sci. 3: 17-32.

Divya, K. 2015. Combined effects of Piriformospora indica and Azotobacter chrococcum enhance plant growth, antioxidant potential and steriol glycoside content in Steria rebaudiana, New Phytol. 4: 152-159.

Ghosh, G.R. 1995. Tulasi (genus Ocimum). New Approaches to Medicine and Health (NAMAH) 3, 23-29.

Gomez, K.A. and A.A. Gomez. 1984. Statistical procedures for Agricultural Research. John Wiley and Sons, New York.

Gupta, M.L., A. Khaliq, R. Pandey, R. S. Shukla, H. N. Singh and S. Kumar (2000) Vesicular-Arbuscular Mycorrhizal Fungi Associated with Ocimum spp., J. Herb. Spi. Medi. Plants., 7: 57-63.

Gupta, S.K., J. Prakash and S. Srivastava. 2000. Validation of claim of Tulsi (Ocimium sanctum L) as a Medicinal plant. Indian J. Exp. Biol., 40(7): 765-773.

Harley, J.L. 1989. The significance of mycorrhiza. Mycol. Res., 92: 129-139.

Ikram, A., A.W. Mahmud, M.N. Ghani, M.T. Ibrahim and A.B. Zainal. 1992. Field nursery inoculation of Hevea brasiliensis Muell. Arg. Seedling rootstock with vesicular-arbuscular mycorrhizal (VAM) fungi. Plant and Science. 145 (2), 231-236.

Iyer, B., M.S. Rajput and S. Rajkumar. 2017. Effect of succinate on phosphate solubilization in nitrogen fixing bacteria harbouring chick pea and their effect on plant growth. Microbiol Res. Sep, 202: 43-50.

Lindarman, D. 1983. Nitrogen application increases the metabolism rate and transport of growth promoters in the plants. Int. J. Agric. Crop Sci. 4(4): 187192.

Mirzakhani, 2009. Effect of dual inoculation of Azotobacter and Mycorrhiza with $\mathrm{N}$ and $\mathrm{P}$ fertilizer rates on grain yield and some characteristics of spring Sunflower, Phytopathol., 81: 420425.

Mishra, K.D. and GeethaRai. 2010. Effect of biofertilizers inoculation on growth and yield of dwarf field pea (Pisum sativum L.,) conjuction with different doses of chemical fertilizers. J. Agronomy., 9: 163-168.

Mishustin, E.N. and V.K. Shilnikova. 1969. Free living nitrogen fixing bacteria of the genus Azotobacter: in Soil Biology, Reviews of Research, pp 72-124.

Pacovsky, R.S., E.A. Paul and G.J. Bethlenfalvay. 1985. Nutrition of sorghum plants fertilized with nitrogen or inoculated with Azospirillum brasilense. Plant Soil, 85: 145-148.

Pandey, A. and S. Kumar. 1989. Potential of Azotobacter as biofertilizers for upland agriculture: A review pp. 134-144.

Paul Schiener and Bethlnfalvay. 1995. Utilization of VAM fungi in agriculture and he described VAM may be an alternative to rising agricultural energy and to increase crop yield and fertilizer cost. Can. J. Bot. 271-285.

Rao. 1986. Biological nitrogen fixation by Azotobacter spp, Department of Microbiology, Shanmuga Industries 
Arts and Science College, Tiruvannamalai, Tamil Nadu, India.

Rawia, E.A., M.A. Nemat and H.A. Hamouda. 2009. Evaluate effectiveness of bio and mineral fertilization on the growth parameters and marketable cut flowers of Matthoiola incand L. European J. Envi. Sci., 5: 499-518.

Sandhya, V., S.Z. Ali, M. Grover, G. Reddy and B. Venkateswarlu. 1989. Effect of plant growth promoting Azospirillum spp. on compatible solutes, antioxidant status and plant growth of maize under drought stress. Plant Growth Regul., 62: 21-30.

Sharma S. B., R.Z. Sayyed, M.H. Trivedi and T.A. Gobi. 2013. Phosphate solubilizing microbes: sustainable approach for managing phosphorus deficiency in agricultural soils. Springerplus, 2: 587600.

Shende, S.T., R.G. Apte and T. Singh. 1977. Influence of Azotobacter on germination of rice and cotton seeds, pp 675.

Subba Rao, N.S. 2001. An Appraisal of biofertilizers in India. In: Biotechnology of Biofertilizers. Maximising the Use of Biological Nitrogen Fixation in Agriculture (Ed. S. Kannaiyan) Narosa Pub. House, New Delhi, p 375.

Tisdall, J.M. and J.M Oades. 1982. Organic matter and waste stable aggregate in soils. J. Soil Sci. 33: 141-163.

\section{How to cite this article:}

Harishkumar, J.M., C. Karishmaa, N. Meenaloshini, K. Nagavalli, P. Pavithra, A. Sowbejan, S.J. Aruna and Theradimani, M. 2019. Effect of Biofertilizers and Vesicular Arbuscular Mycorrhizae on Holy Basil (Ocimum sanctum). Int.J.Curr.Microbiol.App.Sci. 8(06): 13161326. doi: https://doi.org/10.20546/ijcmas.2019.806.159 